\title{
Nanosized titanium dioxide-induced premature ovarian failure is associated with abnormalities in serum parameters in female mice
}

This article was published in the following Dove Press journal: International Journal of Nanomedicine

\author{
Fashui Hong ${ }^{1-4}$ \\ Ling Wang ${ }^{5}$ \\ 'Jiangsu Collaborative Innovation \\ Center of Regional Modern \\ Agriculture and Environmental \\ Protection, Huaiyin Normal \\ University, Huaian, People's Republic \\ of China; ${ }^{2}$ Jiangsu Key Laboratory \\ for Food Safety and Nutrition \\ Function Evaluation, Huaiyin Normal \\ University, Huaian, People's Republic \\ of China; ${ }^{3}$ Jiangsu Key Laboratory \\ for Eco-Agricultural Biotechnology \\ Around Hongze Lake, Huaiyin Normal \\ University, Huaian, People's Republic \\ of China; ${ }^{4}$ School of Life Sciences, \\ Huaiyin Normal University, Huaian, \\ People's Republic of China; ${ }^{5}$ Library \\ of Soochow University, Suzhou, \\ People's Republic of China
}

Background: Exposure to titanium dioxide nanoparticles $\left(\mathrm{TiO}_{2} \mathrm{NPs}\right)$ that are widely used in food, medicine, sunscreen products and cosmetics is reported to cause ovarian damage and lower fertility in animals. However, the potential effects of $\mathrm{TiO}_{2} \mathrm{NPs}$ application on premature ovarian failure (POF) have rarely been evaluated to date.

Methods: In this study, female mice were continuously exposed to $\mathrm{TiO}_{2} \mathrm{NPs}$ at doses of 2.5, 5 or $10 \mathrm{mg} / \mathrm{kg}$ via gavage instillation for 30 days, and investigated the serum hormones and autoimmunity markers associated with POF.

Results: Exposure to $\mathrm{TiO}_{2}$ NPs resulted in POF, reductions in the levels of estradiol, progesterone and inhibin $\mathrm{B}$ and increases in luteinizing hormone, follicle-stimulating hormone, folliclestimulating hormone/luteinizing hormone ratio, anti-Müllerian hormone, thyroid-stimulating hormone, free triiodothyronine, free tetraiodothyronine, anti-nuclear antibody and anti-thyroid peroxidase antibody levels in serum.

Conclusion: Exposure to $\mathrm{TiO}_{2}$ NPs induced POF triggered by alterations in hormones and autoimmunity markers. Our findings highlight the necessity for significant caution in handling and usage of $\mathrm{TiO}_{2} \mathrm{NPs}$ by female consumers.

Keywords: titanium dioxide nanoparticles, mice, premature ovarian failure, serum hormone levels, autoimmunity levels

\section{Introduction}

Titanium dioxide nanoparticles $\left(\mathrm{TiO}_{2} \mathrm{NPs}\right)$ are increasingly used as non-toxic, chemically inert and biocompatible pigment products or photocatalysts owing to their high surface area to particle mass ratio and high reactivity and are commercially manufactured for use in industry, comprehensive ecological improvement, food, medical, diagnostic and cosmetic applications in preference to bulk $\mathrm{TiO}_{2} \cdot{ }^{1,2}$ However, the increased use of $\mathrm{TiO}_{2} \mathrm{NPs}$ in various applications is significantly associated with potential human toxicity.

Recent published data support the toxicity of NPs in the reproductive system. ${ }^{3,4}$ For example, Yoshida et $\mathrm{al}^{5}$ showed that exposure to black carbon NPs leads to adverse effects on male reproductive function in mice, characterized by increased serum testosterone and partial vacuolation of seminiferous tubules. Bai et $\mathrm{al}^{6}$ observed that exposure to water-soluble multiwalled carbon nanotubes leads to oxidative stress in mouse testis. Amorphous nanosilica particles can cross the blood-testis barrier and nuclear membranes of spermatocytes in mouse testis. ${ }^{7}$ In particular, it has been reported that $\mathrm{TiO}_{2} \mathrm{NPs}$ exposure damages follicles, reduces follicular survival and inhibits development and oocyte maturation of rat preantral follicles. ${ }^{8}$ Di Virgilio et $\mathrm{al}^{9}$ demonstrated genotoxicity
Correspondence: Fashui Hong School of Life Sciences, Huaiyin Normal University, Changjiang West Road No. III, Huaian 223300 ,

People's Republic of China

Tel +8651783525992

Email hongfsh_cn@sina.com (c)
hereby accept the Terms. Non-commercial uses of the work are permitted without any further permission from Dove Medical Press Limited, provided the work is properly attributed. For permission for commercial use of this work, please see paragraphs 4.2 and 5 of our Terms (https://www.dovepress.com/terms.php). 
and cytotoxicity following $\mathrm{TiO}_{2}$ or aluminum oxide $\left(\mathrm{Al}_{2} \mathrm{O}_{3}\right)$ NPs exposure in Chinese hamster ovary (CHO-K1) cells. Moreover, $\mathrm{TiO}_{2}$ NPs exposure is associated with reduced sperm number and motility or elevated abnormal sperm number and germ cell apoptosis in mouse testis. ${ }^{10}$ Previous studies indicate that $\mathrm{TiO}_{2}$ NPs cross the blood-testis barrier to reach the testis and accumulate within, causing testicular lesions, sperm malformations and alterations in hormone levels and gene expression profiles in male mice. ${ }^{11-14}$ Importantly, we additionally showed that $\mathrm{TiO}_{2}$ NPs can translocate to and accumulate in the ovary, leading to reductions in body weight (BW), ovarian indices and fertility, inflammation, follicular atresia and necrosis as well as alterations in gene expression in female mice. ${ }^{15-17}$ Liu et al ${ }^{18}$ suggested that nano-zinc oxide $(\mathrm{ZnO})$ exposure affects ovarian development through regulating the number of neuroendocrine cells in the ovary and expression of neuronal factors. This study was conducted to examine the hypothesis that $\mathrm{TiO}_{2} \mathrm{NP}$-mediated suppression of fertility is also associated with premature ovarian failure (POF) in female mice.

POF is a primary ovarian defect characterized by absent menarche (primary amenorrhea) or premature depletion of ovarian follicles before the age of 40 years. POF is considered an immunological disorder that is potentially associated with several factors, including autoimmune disease, ${ }^{19}$ ovarian lymphocytic infiltration, ${ }^{20}$ presence of anti-ovarian antibodies ${ }^{21}$ and post-immunotherapy reversibility, ${ }^{22}$ as well as toxics and drugs in women. ${ }^{23}$ The defect is biochemically typified by low levels of gonadal hormones (estrogens and inhibins) and high levels of gonadotropins (luteinizing hormone [LH] and folliclestimulating hormone [FSH] $)^{24}$ and often associated with nonorgan-specific autoantibodies, such as anti-nuclear antibodies (ANAs) ${ }^{25}$ and anti-thyroid peroxidase antibodies (TPO-Abs), ${ }^{26}$ indicative of altered autoimmunity in these patients. However, the issue of whether $\mathrm{TiO}_{2}$ NPs exposure triggers alterations in autoimmunity remains unclear at present.

Here, female mice were continuously exposed to $\mathrm{TiO}_{2}$ NPs at doses of $2.5,5$ or $10 \mathrm{mg} / \mathrm{kg}$ via gavage instillation for 30 days. Changes in serum parameters were assessed with the aim of establishing whether $\mathrm{TiO}_{2} \mathrm{NPs}_{\text {exposure is linked }}$ to POF and the underlying mechanisms in mice.

\section{Methods}

\section{Chemicals}

Nanoscale $\mathrm{TiO}_{2}$ (anatase, $\mathrm{TiO}_{2}$ content $>99.5 \%$ ) was kindly provided by Professor Yang Ping (Chemical College of Soochow University, Suzhou, China). $\mathrm{TiO}_{2}$ NPs were characterized according to the procedures in the previous studies. ${ }^{27,28}$
The average particle size of $\mathrm{TiO}_{2}$ NPs suspended in $0.5 \%$ (w/v) hydroxypropyl methylcellulose (HPMC) solvent after $24 \mathrm{~h}$ incubation ranged from 5 to $6 \mathrm{~nm}$ based on $\mathrm{X}$-ray diffraction patterns (Mercury CCD Corporation, Japan) and Tecnai G220 transmission electron microscopy (TEM) (FEI Corporation, USA) data, and hydrodynamic diameters of $\mathrm{TiO}_{2}$ NPs in suspension ranged from 208 to $330 \mathrm{~nm}$ (mainly $\sim 294 \mathrm{~nm}$ ) as determined by dynamic light scattering (Brookhaven Instruments Corporation, USA). The surface area of $\mathrm{TiO}_{2}$ NPs was determined to be $174.8 \mathrm{~m}^{2} / \mathrm{g}$ based on Brunauer-Emmett-Teller adsorption measurements on a Micromeritics ASAP 2020M+ C instrument (Micromeritics Corporation, USA) and $\zeta$ potential was determined to be $9.28 \mathrm{mV}$ using the Zeta PALS+BI-90 Plus analyzer (Brookhaven Instruments Corp.)..$^{27,28}$

\section{Ethics approval}

All animal experiments were conducted during the light phase and approved by the Animal Experimental Committee of Soochow University (ethical approval number: 2111270). Procedures were performed in accordance with the National Institutes of Health Guidelines for the Care and Use of Laboratory Animals.

\section{Animals and treatment}

Female specific pathogen-free (SPF) mice aged 4 weeks were used for this study. In total, 200 SPF female and 40 SPF male mice (18 $\pm 2 \mathrm{~g}$ ) were purchased from the Animal Center of Soochow University (China). All mice were housed in stainless steel cages in a ventilated animal room. The room temperature of the housing facility was maintained at $24^{\circ} \mathrm{C} \pm 2{ }^{\circ} \mathrm{C}$ and a relative humidity of $60 \% \pm 10 \%$ under a 12-h light/dark cycle. Distilled water and sterilized food for mice were available ad libitum. After acclimatization to laboratory conditions for 1 week, mice were fasted for $3 \mathrm{~h}$ prior to $\mathrm{TiO}_{2}$ NPs administration.

$\mathrm{TiO}_{2} \mathrm{NP}$ powder was dispersed onto the surface of $0.5 \%$ w/v HPMC, and the suspension containing $\mathrm{TiO}_{2} \mathrm{NPs}_{\mathrm{s}}$ was treated ultrasonically for $30 \mathrm{~min}$ and mechanically vibrated for $5 \mathrm{~min}$. Mice were randomly divided into four groups $(n=50$ each), including a control group treated with $0.5 \% \mathrm{w} / \mathrm{v}$ HPMC and three experimental groups administered $2.5,5$ or $10 \mathrm{mg} / \mathrm{kg}$ of $\mathrm{TiO}_{2}$ NPs. Next, mice were weighed, and the volume of fresh $\mathrm{TiO}_{2}$ NPs suspensions required for each animal was calculated. Fresh $\mathrm{TiO}_{2}$ NPs suspensions were administered to mice via a gavage needle every day for 30 days. For appropriate dose selection, we referred to a report of the World Health Organization in 1969 , according to which $\mathrm{LD}_{50}$ of 
$\mathrm{TiO}_{2}$ for rats is $>12 \mathrm{~g} / \mathrm{kg} \mathrm{BW}$ after oral administration. We additionally referred to previous studies, ${ }^{15,16}$ which showed that the National Institute for Occupational Safety and Health (NIOSH) recommends exposure limits of $2-3 \mathrm{mg} / \mathrm{m}^{3}$ for fine $\mathrm{TiO}_{2}$ and $0.3-1 \mathrm{mg} / \mathrm{m}^{3}$ for ultrafine (including nanoscale engineered) $\mathrm{TiO}_{2} \cdot{ }^{29}$ The doses of $\mathrm{TiO}_{2}$ NPs selected for the study $(2.5,5$ and $10 \mathrm{mg} / \mathrm{kg})$ were equivalent to $\sim 0.15-0.7 \mathrm{~g}$ exposure for humans with $60-70 \mathrm{~kg} \mathrm{BW}$, representative of relatively safe doses.

\section{Mating of animals}

To evaluate the effects of $\mathrm{TiO}_{2}$ NPs on fertility, we treated three groups of female mice (10 per mating group). In total, 10 male and 10 control or treated female mice from each group were placed in a common cage for mating after 30 days of $\mathrm{TiO}_{2}$ NPs administration. Mating success was confirmed based on the formation of a white suppository at the mouth of the vagina tracked via vaginal smearing under an optical microscope (U-III Multi-point Sensor System; Nikon Corporation, Tokyo, Japan). Mating success was assessed by counting the number of pregnant mice.

\section{BW and ovary weight}

After 30 days, all mice were weighed. Blood samples were collected from the eye vein following rapid removal of the eyeball. After collecting blood, all mice were sacrificed via cervical dislocation, and ovaries of all animals were quickly removed, weighed, placed on ice and dissected and frozen at $-80^{\circ} \mathrm{C}$ (with the exception of 40 ovaries that were used for histopathological examination). Serum was collected by centrifuging blood at $1,200 \times g$ for $10 \mathrm{~min}$.

\section{Serum parameter analysis}

Plasma concentrations of anti-Müllerian hormone (AMH), inhibin B, estradiol (E2), progesterone (P), LH, FSH, prolactin (PRL), thyroid-stimulating hormone (TSH), free triiodothyronine (fT3) and free tetraiodothyronine (fT4) were detected with the aid of commercial kits (Bühlmann Laboratories AG, Switzerland). The levels of ANAs and anti-TPO-Abs were measured using enzyme-linked immunosorbent assay (ELISA; R\&D Systems, Inc., Minneapolis, MN, USA). All biochemical assays were performed using an automated clinical chemistry analyzer (Type 7170A; Hitachi Ltd., Tokyo, Japan).

\section{Histopathological evaluation of ovary}

All histopathological examinations were performed using standard laboratory procedures. Five sets of ovarian tissues from mice were embedded in paraffin blocks, sliced into $5 \mu \mathrm{m}$ sections and placed on separate glass slides (five slices from each kidney). After hematoxylin-eosin staining, sections were evaluated by a histopathologist blinded to the treatments under an optical microscope (U-III Multi-point Sensor System; Nikon Corporation).

\section{Statistical analysis}

Data are presented as mean \pm SD. Statistical analyses were performed using SPSS 19.0 software (IBM Corporation, Armonk, NY, USA) and compared via one-way analysis of variance (ANOVA) followed by Tukey's HSD post-hoc test. Differences were considered statistically significant at $p$-values $<0.05$.

\section{Results}

\section{Body and ovarian weights}

Figure 1 depicts the effects of $\mathrm{TiO}_{2}$ NPs exposure on net increase in body and ovarian weights. $\mathrm{TiO}_{2} \mathrm{NPs}$ treatment induced a significant reduction in the net increase in BW $(-7.81 \%$ to $-35.87 \%)$ and ovarian weight ( $-16.32 \%$ to $-61.44 \%)$, compared with the control group $(p<0.05)$. The decrease in ovarian weight caused by $\mathrm{TiO}_{2}$ NPs is suggestive of ovarian atrophy and may be related to tissue injury or POF, as confirmed by histopathological observation of mouse ovaries.

\section{Reproduction}

In response to increasing $\mathrm{TiO}_{2} \mathrm{NP}$ doses, the mating and pregnancy rates of mice were significantly decreased by $14 \%-31 \%$ and $17 \%-40 \%$, respectively, as shown in Figure 2 $(p<0.05)$. The decreased pregnancy rate may be associated with POF triggered by $\mathrm{TiO}_{2}$ NPs exposure.

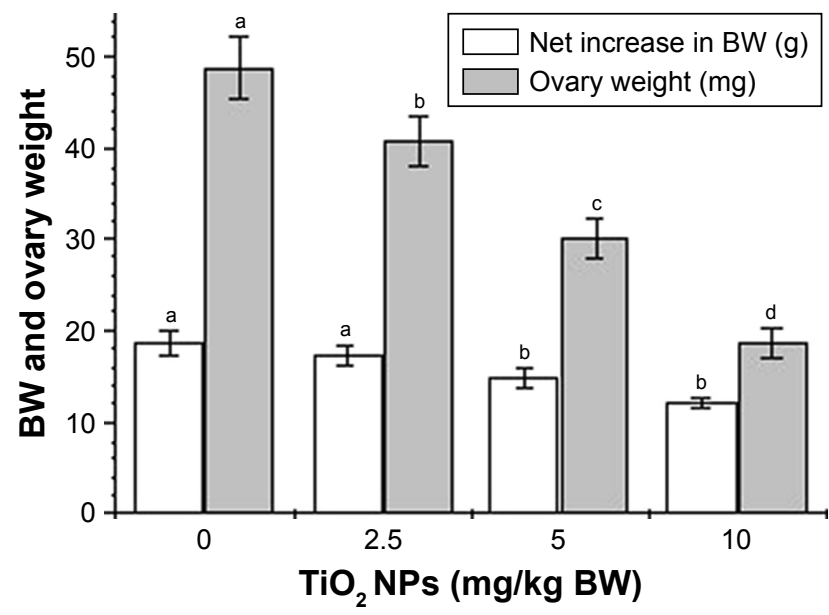

Figure I Effects of $\mathrm{TiO}_{2} \mathrm{NPs}$ on net increase in $\mathrm{BW}$ and ovarian weight after gavage administration for 30 days.

Notes: Different letters within the same parameter indicate significant differences between groups $(p<0.05)$. Values represent mean $\pm S D(n=10)$.

Abbreviations: $\mathrm{BW}$, body weight; $\mathrm{TiO}_{2} \mathrm{NPs}$, titanium dioxide nanoparticles. 


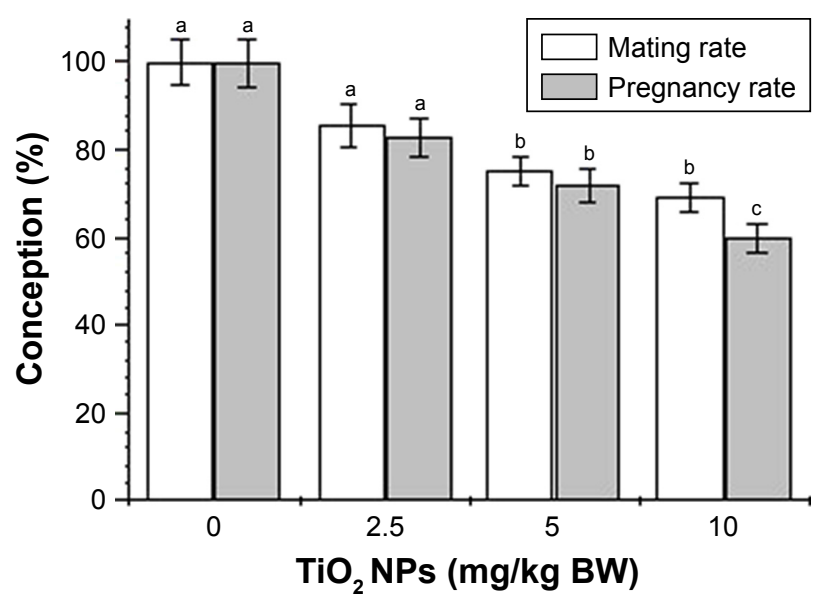

Figure 2 Effect of $\mathrm{TiO}_{2} \mathrm{NPs}$ on conception in female mice after gavage administration for 30 days.

Notes: Different letters within the same parameter indicate significant differences between groups $(p<0.05)$. Values represent mean \pm SD $(n=10)$.

Abbreviations: $\mathrm{BW}$, body weight; $\mathrm{TiO}_{2} \mathrm{NPs}$, titanium dioxide nanoparticles.

\section{Histopathological evaluation}

The histological changes in mouse ovary are presented in Figure 3. Normal development of primary follicles from control ovary was observed (Figure 3). However, samples from the $2.5 \mathrm{mg} / \mathrm{kg} \mathrm{TiO}{ }_{2} \mathrm{NP}$-exposed group showed not only atrophic secondary follicles but also a large number of primary atretic follicles and disposed disorder or apoptosis of granule cells. Similarly, the $5 \mathrm{mg} / \mathrm{kg} \mathrm{TiO}_{2} \mathrm{NP}$-exposed group exhibited a large increase in primary atretic follicle number and disposed disorder or apoptosis of granule cells, and the $10 \mathrm{mg} / \mathrm{kg} \mathrm{TiO}$ NP-exposed group showed severe inflammatory cell infiltration along with increased primary atretic follicle content and disposed disorder or apoptosis of granule cells in the ovary (Figure 3). Our collective results support the theory that $\mathrm{TiO}_{2}$ NPs exposure induces POF in female mice.

\section{Serum parameters}

As shown in Table 1, serum FSH, LH, FSH/LH ratio, AMH, PRL, TSH, fT3 and fT4 levels were significantly increased, whereas inhibin B, E2 and P levels were markedly reduced with increasing $\mathrm{TiO}_{2} \mathrm{NP}$ doses $(p<0.05)$. Notably, the levels of serum ANAs and TPO-Abs involved in the autoimmune response were gradually increased with exposure to increasing concentrations of $\mathrm{TiO}_{2} \mathrm{NPs}$ in female mice (Table $1, p<0.05$ ).

B

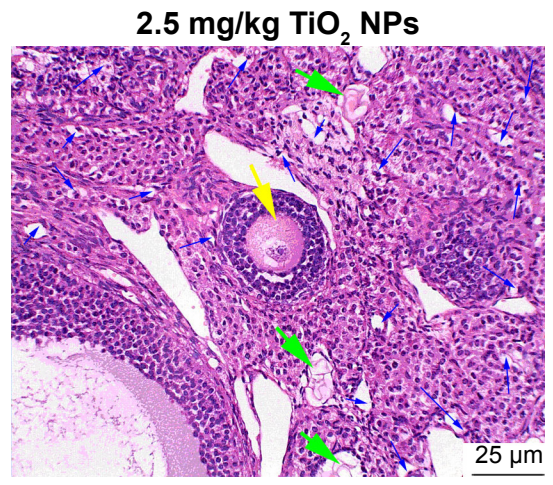

D

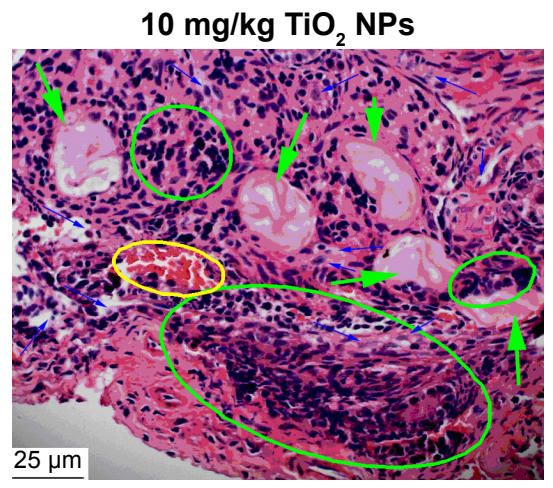

Figure 3 Histopathological examination of ovary of mice following gavage administration of $\mathrm{TiO}_{2} \mathrm{NPs}_{\text {s }} 30$ days.

Notes: (A) Control groups (unexposed mice) present normal development of primary follicles (black arrow) and secondary follicles (yellow arrow); (B) the $2.5 \mathrm{mg} / \mathrm{kg} \mathrm{TiO}{ }_{2}$ $\mathrm{NP}$-exposed group shows atrophic secondary follicle (yellow arrow), primary follicle atresia (green arrow) and apoptosis of granule cells (blue arrow); (C) the $5 \mathrm{mg} / \mathrm{kg} \mathrm{TiO}{ }_{2} \mathrm{NP}$ exposed group shows large primary follicle atresia (green arrow) and granule cell apoptosis (blue arrow), and (D) the $10 \mathrm{mg} / \mathrm{kg}^{\mathrm{TiO}} \mathrm{NP}_{2}$-exposed group shows severe inflammatory cell infiltration (green circle), congestion (yellow circle), significant primary follicle atresia (green arrow) and disposed disorder or apoptosis of granule cells (blue arrow). Abbreviation: $\mathrm{TiO}_{2} \mathrm{NPs}$, titanium dioxide nanoparticles. 
Table I Changes in serum parameters involved in autoimmune response in female mice caused by gavage administration of $\mathrm{TiO}_{2} \mathrm{NPs}_{\mathrm{s}}$ for 30 days

\begin{tabular}{|c|c|c|c|c|}
\hline \multirow[t]{2}{*}{ Serum parameters } & \multicolumn{4}{|c|}{$\mathrm{TiO}_{2}$ NPs (mg/kg BW) } \\
\hline & Control & 2.5 & 5 & 10 \\
\hline FSH (IU/L) & $2.28 \pm 0.3 \mathrm{I}^{\mathrm{a}}$ & $3.98 \pm 0.45^{b}$ & $4.05 \pm 0.4 \mathrm{I}^{\mathrm{b}}$ & $6.79 \pm 0.78^{c}$ \\
\hline LH (IU/L) & $2.35 \pm 0.26^{\mathrm{a}}$ & $3.31 \pm 0.36^{b}$ & $3.39 \pm 0.39^{b}$ & $4.90 \pm 0.58^{c}$ \\
\hline Ratio of FSH/LH & $0.97 \pm 0.14^{\mathrm{a}}$ & $1.10 \pm 0.17^{\mathrm{a}}$ & $1.4 \mathrm{I} \pm 0.18^{\mathrm{b}}$ & $\mathrm{I} .49 \pm 0.2 \mathrm{I}^{\mathrm{b}}$ \\
\hline AMH (pmol/L) & $10.79 \pm 1.25^{\mathrm{a}}$ & $11.21 \pm 1.35^{\mathrm{a}}$ & $14.86 \pm 1.6 \mathrm{I}^{\mathrm{b}}$ & $19.09 \pm 2.08^{c}$ \\
\hline Inhibin B (pg/mL) & $36.59 \pm 3.27^{a}$ & $28.82 \pm 3.12^{\mathrm{b}}$ & $27.66 \pm 2.49^{b}$ & $15.03 \pm 1.15^{c}$ \\
\hline E2 (pmol/L) & $152.16 \pm|2.3|^{a}$ & $145.29 \pm 16.74^{a}$ & $\mid 20.5 \mathrm{I} \pm 14.3 \mathrm{I}^{\mathrm{b}}$ & $111.36 \pm 9.91^{b}$ \\
\hline $\mathrm{P}(\mathrm{nmol} / \mathrm{L})$ & $30.29 \pm 3.02^{\mathrm{a}}$ & $25.25 \pm 2.76^{\mathrm{b}}$ & $23.67 \pm 2.43^{b}$ & $11.72 \pm 1.29^{c}$ \\
\hline PRL $(\mu g / L)$ & $0.87 \pm 0.1 \mathrm{I}^{\mathrm{a}}$ & $1.02 \pm 0.16^{\mathrm{a}}$ & $\mathrm{I} .75 \pm 0.22^{\mathrm{b}}$ & $1.89 \pm 0.25^{\mathrm{b}}$ \\
\hline $\mathrm{TSH}(\mathrm{pg} / \mathrm{mL})$ & $53.4 \pm 5.67^{\mathrm{a}}$ & $40.9 \pm 4.25^{b}$ & $38.1 \pm 3.92^{\mathrm{b}}$ & $34.8 \pm 3.6 \mathrm{I}^{\mathrm{b}}$ \\
\hline fT3 (pmol/L) & $18.71 \pm 1.94^{\mathrm{a}}$ & $24.75 \pm 2.88^{b}$ & $27.96 \pm 2.93^{b}$ & $30.77 \pm 3.74^{b}$ \\
\hline $\mathrm{fT} 4(\mu \mathrm{g} / \mathrm{L})$ & $97.45 \pm 9.87^{\mathrm{a}}$ & $131.23 \pm 15.13^{b}$ & $199.10 \pm 20.62^{c}$ & $210.62 \pm 23.51^{c}$ \\
\hline ANA (ng/L) & $25.25 \pm 2.7 I^{a}$ & $29.44 \pm 3.3 \mathrm{I}^{\mathrm{a}}$ & $36.87 \pm 3.82^{\mathrm{b}}$ & $38.56 \pm 4.09 c$ \\
\hline TPO-Ab (mU/L) & $149.05 \pm 15.48^{\mathrm{a}}$ & $160.53 \pm 19.15^{a}$ & $213.08 \pm 22.63^{b}$ & $226.09 \pm 24.12^{c}$ \\
\hline
\end{tabular}

Notes: Different letters within the same parameter indicate significant differences between groups $(p<0.05)$. Values represent mean \pm SD $(n=5)$.

Abbreviations: $\mathrm{AMH}$, anti-Müllerian hormone; ANA, anti-nuclear antibody; BW, body weight; FSH, follicle-stimulating hormone; fT3, free triiodothyronine; fT4, free tetraiodothyronine; $\mathrm{LH}$, luteinizing hormone; PRL, prolactin; $\mathrm{TiO}_{2} \mathrm{NPs}$, titanium dioxide nanoparticles; TPO-Ab, thyroid peroxidase antibody; TSH, thyroid-stimulating hormone.

\section{Discussion}

To determine the potential effects of $\mathrm{TiO}_{2} \mathrm{NPs}$ exposure on POF of female mice, we focused on histopathological changes in ovary, fertility, and hormone and anti-ovarian antibody levels in serum in the present study. Exposure to 2.5, 5 and $10 \mathrm{mg} / \mathrm{kg} \mathrm{BW} \mathrm{TiO} 2$ NPs for 30 days led to significant reductions in body and ovarian weights (Figure 1) and mating and pregnancy rates (Figure 2), severe inflammation, and follicle atresia as well as apoptosis of granule cells in the ovary (Figure 3), consistent with our previous findings. ${ }^{15-17}$ These characteristics contribute to POF following $\mathrm{TiO}_{2} \mathrm{NP}$-induced toxicity, which may be attributable to $\mathrm{TiO}_{2} \mathrm{NP}$ accumulation in ovary ${ }^{15}$ or biokinetics in vivo after oral application. ${ }^{30-32}$ Furthermore, $\mathrm{TiO}_{2}$ NPs induced a decrease in inhibin B, E2 and $\mathrm{P}$ levels and an increase in $\mathrm{FSH}, \mathrm{LH}, \mathrm{FSH} / \mathrm{LH}$ ratio, AMH, PRL, TSH, fT3, fT4, ANA and TPO-Ab levels in mouse sera (Table 1), as discussed subsequently.

Gonadotrophin-releasing hormone (GnRH), FSH and LH regulate ovarian function through a sensitive feedback system. Elevated serum FSH in the early follicular phase, a consequence of reduced ovarian function, is predictive of impaired pregnancy outcomes after infertility treatment, ${ }^{33}$ and a combination of low FSH and high LH levels can be utilized to predict pregnancy outcomes. ${ }^{34}$ The FSH:LH ratio has been successfully applied as a predictor of pregnancy outcomes in infertile women. ${ }^{23}$ Elevated serum FSH, LH and FSH:LH ratio observed in the present study are clearly suggestive of impaired ovarian function due to $\mathrm{TiO}_{2} \mathrm{NPs}$ exposure in mice.
AMH is a dimeric glycoprotein generated by granulosa cells from pre-antral and antral follicles that mainly function to inhibit follicular development from the primordial to primary follicular stage. During the menstrual cycle, serum AMH levels are relatively stable. ${ }^{35}$ Additionally, AMH is reported to be a better predictor of pregnancy outcome than other hormonal parameters. ${ }^{36,37}$ Inhibin B, produced by granulosa cells in antral follicles, has been proposed as an effective marker of follicular growth. Low serum inhibin B levels are associated with elevated FSH levels, leading to reduction in oocyte quality and fertility. ${ }^{35}$ Therefore, increased AMH and decreased inhibin $\mathrm{B}$ levels in serum induced by $\mathrm{TiO}_{2} \mathrm{NPs}$ exposure may be closely linked to POF generation in mice.

Estrogen plays important roles in oocyte maturation, embryo quality and fertilization..$^{38,39}$ The most important estrogen is E2 in serum, ${ }^{10}$ which, in combination with FSH and age, is predictive of pregnancy outcomes after in vitro fertilization treatment. ${ }^{40}$ Progesterone is the most important hormone for endometrial development, implantation and maintenance of pregnancy, ${ }^{41}$ and its activity during the luteal phase can increase pregnancy as well as live birth rates after infertility treatment. ${ }^{42,43}$ In the present study, lower serum E2 and $\mathrm{P}$ levels were associated with reduced mating and pregnancy rates in $\mathrm{TiO}_{2}$ NP-exposed female mice.

Thyroid hormones influence ovarian function directly and indirectly through elevation of PRL levels and alterations in GnRH secretion. Ovarian insufficiencies often occur in women with thyroid dysfunction. ${ }^{44}$ Increased serum PRL levels are related to menstrual disorders because 
of their restraining effect on pulsatile GnRH secretion as well as inhibition of FSH and LH release. ${ }^{45}$ Importantly, hyperprolactinemia is suggested to be associated with ovulatory dysfunction, ${ }^{46}$ and both hypothyroidism and hyperprolactinemia are linked to infertility. However, the specific association between pregnancy outcome and serum TSH levels is a subject of controversy at present. For example, Cramer and co-workers suggested that infertile women with increased serum TSH levels have lower pregnancy rates than those with normal TSH levels. ${ }^{47}$ Arojoki et al reported low serum TSH levels in women with infrequent menstruation and female infertility and high serum TSH levels in women with unexplained infertility and ovulatory dysfunction. ${ }^{48}$ In our study, PRL, TSH, fT3 and fT4 levels were significantly increased in $\mathrm{TiO}_{2} \mathrm{NP}$-exposed female mice, suggesting that these factors are correlated with ovulatory dysfunction and low fertility due to POF.

Earlier reports indicate that $10.5 \%$ infertile women are positive for antithyroid antibodies (ATAs), ${ }^{48}$ and TPO-Abs are associated with the TSH levels. ${ }^{49}$ For instance, TPOAb-positive women have significantly elevated TSH levels, whereas a number of women with normal TSH levels are positive for TPO-Abs. ${ }^{50,51}$ The presence of ATAs in euthyroid women may be related to fertility problems, including increased abortion rate and incidence of infertility. ${ }^{24}$ In addition, the incidence of ANAs in patients with POF was demonstrated to be higher than that in age-matched hypogonadotropic patients with secondary amenorrhea, refuting a potential role of hypoestrogenism in the formation of ANAs. ${ }^{24}$ Data from this study collectively suggest that exposure to $\mathrm{TiO}_{2}$ NPs induces significant elevation of serum ANA and TPO-Ab levels in female mice, which may also be associated with altered autoimmunity, leading to POF.

\section{Conclusion}

Exposure of female mice to $\mathrm{TiO}_{2}$ NPs results in POF characterized by a reduction in reproductive ability along with decreased levels of inhibin B, E2 and $\mathrm{P}$ and increased FSH, $\mathrm{LH}, \mathrm{FSH} / \mathrm{LH}$ ratio, AMH, PRL, TSH, fT3, fT4, ANA and TPO-Ab levels in serum. Our results support the crucial need to improve public awareness of the hazards of oral exposure to $\mathrm{TiO}_{2}$ NPs for female consumers.

\section{Acknowledgment}

This work was supported by the National Natural Science Foundation of China (grant numbers 81473007, 31671033, 81273036 and 30901218), the National Natural Science Foundation of Jiangsu Province (grant number BK20161306) and the Top-notch Academic Programs Project of Jiangsu Higher Education Institutions (PPZY2015A018).

\section{Disclosure}

The authors report no conflicts of interest in this work.

\section{References}

1. Roco MS, Bainbridge WS, editors. Societal Implications of Nanoscience and Nanotechnology. Norwell, MA: National Science Foundation, NSET Workshop Report Kluwer Academic Publishers; 2001.

2. Jortner J, Rao CNR. Nanostructured advanced materials: perspectives and directions. Pure Appl Chem. 2002;74(9):1491-1506.

3. Hong FS, Yu XH, Wu N, et al. Progress of in vivo studies on the systemic toxicities induced by titanium dioxide nanoparticles. Toxicol Res. 2017;6:115-133.

4. Alaee S, Ilani M. Effect of titanium dioxide nanoparticles on male and female reproductive systems. J Adv Med Sci Appl Technol. 2017; 3(1):3-8.

5. Yoshida S, Hiyoshi K, Ichinose T, et al. Effect of nanoparticles on the male reproductive system of mice. Int J Androl. 2008;32(4):337-342.

6. Bai YH, Zhang Y, Zhang JP, et al. Repeated administrations of carbon nanotubes in male mice cause reversible testis damage without affecting fertility. Nat Nanotechnol. 2010;5:683-689.

7. Morishita Y, Yoshioka Y, Satoh H, et al. Distribution and histologic effects of intravenously administered amorphous nanosilica particles in the testes of mice. Biochem Biophys Res Commun. 2012;420(2):297-301.

8. Hou J, Wan XY, Wang F, et al. [Effects of titanium dioxide nanoparticles on development and maturation of rat preantral follicle in vitro]. Acad J Second Mil Med Univ. 2009;30(8):869-873. [Chinese with English abstract].

9. Di Virgilio AL, Reigosa M, Arnal PM, Fernández Lorenzo de Mele M. Comparative study of the cytotoxic and genotoxic effects of titanium oxide and aluminium oxide nanoparticles in Chinese hamster ovary (CHO-K1) cells. J Hazard Mater. 2010;177(1-3):711-718.

10. Guo LL, Liu XH, Qin DX, et al. [Effects of nanosized titanium dioxide on the reproductive system of male mice]. Zhonghua Nan Ke Xue. 2009;15(6):517-522. [Chinese with English abstract].

11. Gao GD, Ze YG, Zhao XY, et al. Titanium dioxide nanoparticle-induced testicular damage, spermatogenesis suppression, and gene expression alterations in male mice. J Hazard Mater. 2013;258-259:133-143.

12. Hong FS, Zhao XY, Si WH, et al. Decreased spermatogenesis led to alterations testis-specific gene expression in male mice following exposure to nano- $\mathrm{TiO}_{2}$. J Hazard Mater. 2015;300:718-728.

13. Hong FS, $\mathrm{Si} \mathrm{WH}, \mathrm{Zhao} \mathrm{XY}$, et al. $\mathrm{TiO}_{2}$ nanoparticles exposure decreases spermatogenesis via biochemical dysfunctions in the testis of male mice. J Agric Food Chem. 2015;63(31):7084-7092.

14. Hong FS, Wang YJ, Zhou YJ, et al. Exposure to $\mathrm{TiO}_{2}$ nanoparticles induces immunological dysfunction in mouse testitis. $J$ Agric Food Chem. 2016;64(1):346-355.

15. Gao GD, Ze YG, Li B, et al. The ovarian dysfunction and its geneexpressed characteristics of female mice caused by long-term exposure to titanium dioxide nanoparticles. $J$ Hazard Mater. 2012;243:19-27.

16. Zhao XY, Ze YG, Gao GD, et al. Nanosized $\mathrm{TiO}_{2}$-induced reproductive system dysfunction and its mechanism in female mice. PLoS One. 2013; 8(4):e59378.

17. Hong F, Zhou Y, Zhao X, Sheng L, Wang L. Maternal exposure to nanosized titanium dioxide suppresses embryonic development in mice. Int J Nanomedicine. 2017;12:6197-6204.

18. Liu XQ, Zhang HF, Zhang WD, et al. Regulation of neuroendocrine cells and neuron factors in the ovary by zinc oxide nanoparticles. Toxicol Lett. 2016;256:19-32.

19. Tung KSK, Lu CY. Immunological basis of reproductive failure. In: Krans FT, Danijanov I, Kaufman N, editors. Pathology of Reproductive Failure. Baltimore: Williams \& Wilkins; 1991:308-333. 
20. Wheatcroft NJ, Toogood AA, Li TC, et al. Detection of antibodies to ovarian antigens in women with premature failure. Clin Exp Immunol. 1994; 96(1):122-128.

21. Corenblum B, Rowe T, Taylor PJ. High doses, short term glucocorticoids for the treatment of infertility resulting from premature ovarian failure. Fertil Steril. 1993;59(5):988-991.

22. Beck-Peccoz P, Persani L. Premature ovarian failure. Orphanet J Rare Dis. 2006;1(1):557-566.

23. Broekmans FJ, Kwee J, Hendriks DJ, Mol BW, Lambalk CB. A systematic review of tests predicting ovarian reserve and IVF outcome. Hum Reprod Update. 2006;12(6):685-718.

24. Ishizuka B, Kudo Y, Amemiya A, Yamada H, Matsuda T, Ogata T. Anti-nuclear antibodies in patients with premature ovarian failure. Hum Reprod. 1999;14(1):70-75.

25. McElduff A, Morris J. Thyroid function tests and thyroid autoantibodies in an unselected population of women undergoing first trimester screening for aneuploidy. Aust N Z J Obstet Gynaecol. 2008; 48(5):478-480.

26. Stagnaro-Green A, Roman SH, Cobin RH, el-Harazy E, AlvarezMarfany M, Davies TF. Detection of at-risk pregnancy by means of highly sensitive assays for thyroid autoantibodies. JAMA. 1990;264(11): 1422-1425.

27. Yang $\mathrm{P}, \mathrm{Lu} \mathrm{C}$, Hua N, et al. Titanium dioxide nanoparticles co-doped with $\mathrm{Fe}^{3+}$ and $\mathrm{Eu}^{3+}$ ions for photocatalysis. Mater Lett. 2002;57(4): 794-801.

28. Hu RP, Zheng L, Zhang T, et al. Molecular mechanism of hippocampal apoptosis of mice following exposure to titanium dioxide nanoparticles. J Hazard Mater. 2011;191(1-3):32-40.

29. National Institute for Occupational Safety and Health (NIOSH). Outlines Guidance on Handling Titanium Dioxide (TiO2). Atlanta: Emerald Group Publishing Limited; 2011.

30. Kreyling WG, Holzwarth U, Haberl N, et al. Quantitative biokinetics of titanium dioxide nanoparticles after intravenous injection in rats: part 1. Nanotoxicology. 2017;11(4):434-442.

31. Kreyling WG, Holzwarth U, Haberl N, et al. Quantitative biokinetics of titanium dioxide nanoparticles after oral application in rats: part 2. Nanotoxicology. 2017;11(4):443-453.

32. Kreyling WG, Holzwarth U, Haberl N, et al. Quantitative biokinetics of titanium dioxide nanoparticles after intratracheal instillation in rats: part 3. Nanotoxicology. 2017;11(4):454-464.

33. Brodin T, Bergh T, Berglund L, Hadziosmanovic N, Holte J. High basal LH levels in combination with low basal FSH levels are associated with high success rates at assisted reproduction. Hum Reprod. 2009; 24(11):2755-2759.

34. Seckin B, Turkcapar F, Ozaksit G. Elevated day 3 FSH/LH ratio: a marker to predict IVF outcome in young and older women. $J$ Assist Reprod Genet. 2011;29(3):231-236.

35. Broekmans FJ, Soules MR, Fauser BC. Ovarian aging: mechanisms and clinical consequences. Endocr Rev. 2009;30(5):465-493.
36. Wu CH, Chen YC, Wu HH, et al. Serum anti-mullerian hormone predicts ovarian response and cycle outcome in IVF patients. J Assist Reprod Genet. 2009;26(7):383-389.

37. Brodin T, Hadziosmanovic N, Berglund L, et al. Antimullerian hormone levels are strongly associated with live-birth rates after assisted reproduction. J Clin Endocrinol Metab. 2013;98(3):1107-1114.

38. Sundarrajan C, Liao W, Roy AC, Ng SC. Association of oestrogen receptor gene polymorphisms with outcome of ovarian stimulation in patients undergoing IVF. Mol Hum Reprod. 1999;5(9):797-802.

39. Sundarrajan C, Liao WX, Roy AC, Ng SC. Association between estrogen receptor-beta gene polymorphisms and ovulatory dysfunctions in patients with menstrual disorders. J Clin Endocrinol Metab. 2001; 86(1):135-139.

40. Srouji SS, Mark A, Levine Z, Betensky RA, Hornstein MD, Ginsburg ES. Predicting in vitro fertilization live birth using stimulation day 6 estradiol, age, and follicle-stimulating hormone. Fertil Steril. 2005; 84(3):795-797.

41. Graham JD, Clarke CL. Physiological action of progesterone in target tissues. Endocr Rev. 1997;18(4):502-519.

42. Bjuresten K, Landgren BM, Hovatta O, Stavreus-Evers A. Luteal phase progesterone increases live birth rate after frozen embryo transfer. Fertil Steril. 2011;95(2):534-537.

43. Erdem A, Erdem M, Atmaca S, Guler I. Impact of luteal phase support on pregnancy rates in intrauterine insemination cycles: a prospective randomized study. Fertil Steril. 2009;91(6):2508-2513.

44. Poppe K, Velkeniers B, Glinoer D. Thyroid disease and female reproduction. Clin Endocrinol (Oxf). 2007;66(3):309-321.

45. Kostrzak A, Warenik-Szymankiewicz A, Meczekalski B. The role of serum PRL bioactivity evaluation in hyperprolactinaemic women with different menstrual disorders. Gynecol Endocrinol. 2009;25(12):799-806.

46. Cramer DW, Sluss PM, Powers RD, et al. Serum prolactin and TSH in an in vitro fertilization population: is there a link between fertilization and thyroid function? J Assist Reprod Genet. 2003;20(6):210-215.

47. Arojoki M, Jokimaa V, Juuti A, Koskinen P, Irjala K, Anttila L. Hypothyroidism among infertile women in Finland. Gynecol Endocrinol. 2000;14(2):127-131.

48. Revelli A, Casano S, Piane LD, et al. A retrospective study on IVF outcome in euthyroid patients with anti-thyroid antibodies: effects of levothyroxine, acetyl-salicylic acid and prednisolone adjuvant treatments. Reprod Biol Endocrinol. 2009;7:137.

49. Prummel MF, Wiersinga WM. Thyroid peroxidase autoantibodies in euthyroid subjects. Best Pract Res Clin Endocrinol Metab. 2005; 19(1):1-15.

50. Debiève F, Dulière S, Bernard P, Hubinont C, De Nayer P, Daumerie C. To treat or not to treat euthyroid autoimmune disorder during pregnancy? Gynecol Obstet Invest. 2009;67(3):178-182.

51. Poppe K, Glinoer D. Thyroid autoimmunity and hypothyroidism before and during pregnancy. Hum Reprod Update. 2003;9(2):149-161.

International Journal of Nanomedicine

\section{Publish your work in this journal}

The International Journal of Nanomedicine is an international, peerreviewed journal focusing on the application of nanotechnology in diagnostics, therapeutics, and drug delivery systems throughout the biomedical field. This journal is indexed on PubMed Central, MedLine, CAS, SciSearch $\AA$, Current Contents ${ }^{\circledR} /$ Clinical Medicine,

Journal Citation Reports/Science Edition, EMBase, Scopus and the Elsevier Bibliographic databases. The manuscript management system is completely online and includes a very quick and fair peer-review system, which is all easy to use. Visit http://www.dovepress.com/ testimonials.php to read real quotes from published authors. 